\title{
O implicitní přítomnosti kriticko-idealistické fáze Marxova myšlení ve fázi dialekticko-historicko materialistické
}

ON THE IMPLICIT PRESENCE OF THE CRITICAL-IDEALISTIC PHASE OF MARX'S THINKING IN

THE DIALECTICAL-HISTORICAL MATERIALISTIC PHASE

\section{Luděk Toman ${ }^{1}$}

\begin{abstract}
Abstrakt: Myšlení Karla Marxe se stalo základem dialekticko-historicko materialistické filosofie a tak zvaného vědeckého komunismu. Marxův filosofický vývoj byl však složitý a před dialekticko-historicko materialistickou a komunistickou fází Marx prošel fází kritického idealismu a byl jedním z mladohegelovských filosofů hlásících se k určitému způsobu interpretace německého filosofa Hegela, kterou byly ospravedlňovány požadavky na radikální společenské změny. Ve stati je ukázáno, že mezi mladší, kriticko-idealistickou, a starší, dialekticko-historicko materialistickou fází je hlubší vztah než temporálně-kauzální či logický, a tento vztah je nazván implicitní prítomností kriticko-idealistické fáze ve fázi dialektickohistoricko materialistické. $V$ důsledku Marxova a Engelsova zásahu do vývoje komunistického hnutí, ve kterém získali vedoucí ideologickou pozici, se radikálně změnila obhajoba komunismu a na základě Marxova a Engelsova príspěvku vzniká tak zvaný vědecký komunismus a socialismus, který se snaží co nejméně argumentovat morálními důvody, ale budoucí vznik komunismu ospravedlňuje jako nutnost dějin, která vyplývá z vědeckého poznání. Tato transformace komunistického ideálu měla zásadní důsledky pro komunistické hnutí a budoucí vznik socialistických systémů, které se ideologicky dovolávaly Marxova učení.
\end{abstract}

Klíčová slova: Marx, komunismus, dialecticko-historický materialismus, kritický-idealismus.

Abstract: Karl Marx's thinking became the basis of dialectical-historical materialist philosophy and so-called scientific communism. Marx's philosophical development was complex and before the dialectical-historical materialist and communist phase Marx had gone through a phase of critical-idealism and had been one of the Young Hegelian philosophers who advocated a certain interpretation of the German philosopher Hegel and this interpretation justified the demands for radical social change. The paper shows that there is a deeper relationship between the younger, critical-idealistic, and older, dialectical-historical materialistic phases than the temporal-causal or logical ones, and this relationship is called the implicit presence of the critical-idealistic phase in the dialectical-historical materialistic phase. As a result of Marx and Engels' intervention in the development of the communist movement, in which they gained a leading ideological position, the defense of communism changed radically and on the basis of the contribution of Marx and Engels so-called scientific communism and socialism arose. It justifies communism through moral arguments as little as possible and justifies it as a necessity of history which follows from scientific knowledge. This transformation of the communist ideal had fundamental consequences for the communist movement and the future emergence of socialist systems that ideologically invoked Marx's teachings.

Keywords: Marx, communism, dialectical-historical materialism, critical-idealism.

\footnotetext{
1 Fakulta mezinárodních vztahů, Vysoká škola ekonomická v Praze, nám. W. Churchilla 4, 13067 Praha 3, tomanl@vse.cz.
} 


\section{Úvod}

Na základě díla Karla Marxe a Bedřicha Engelse vyrostl dialektický a historický materialismus a vědecký socialismus (vědecký komunismus), který byl v pozdějších socialistických státech prohlašován za jediný vědecký základ pro poznávání a dějinnou praxi. Oficiální názor pohlížel na poměrně radikální obrat v Marxově filosofování od kritického idealisty k dialektickému a historickému materialistovi logikou časově-kauzální podmíněnosti tohoto procesu jako na zrání Marxe, jako na vývoj od méně dokonalého k dokonalejšímu stavu, jako na překonávání omylů a iluzí. Podobně jako se podle Darwina z někdejší předlidské a zvířecí bytosti nakonec vyvinula bytost lidská, nebo koneckonců podle samotného „dialekticko-historicko materialistického“ Marxe se měla vývojově nižší fáze lidské společenské formace - kapitalismus „nutně“ transformovat ve fázi vyšší - socialismus a posléze komunismus. Názorové odrůdy marxismu, které vykvetly na Západě, kde nebyla závazná jediná správná interpretace Marxe, se zase často vztahovaly bud' zejména k mladšímu Marxovi, nebo naopak vyzrálému, „dialekticko-historicko materialistickému“ 2 Marxovi, nebo - v určitém zjednodušení - bud' k „Marxovi humanistovi“3 nebo „Marxovi - vědci“. V následujícím textu chci podat výklad Marxova myšlení, který ozřejmí, že první idealisticko-kritická fáze jeho myšlení ve skutečnosti stále zůstala prítomná i ve druhé fázi (a snad ani nemohla nezůstat), byt její výrazivo se měnilo, a důraz Marxovy a Engelsovy argumentace se posunul na nově formulované otázky. Nejen z hlediska dosažených pravd, ale i metody, jak k nim Marx dospěl, je spojení mladšího a vyzrálejšího Marxe na mnohem hlubší úrovni než je úroveň časově-kauzální či logická.

Marxovo myšlení, které je kritickou syntézou myšlenek a závěrů i řady jiných myslitelů, se pokusilo dát lidstvu filosofický a metodologický nástroj, který by mu umožnil být schopné svébytněji a vědoměji rozhodovat o vlastní budoucnosti. Postavit komunistickou budoucnost lidstva na vědeckou úroveň a nahradit tak předchozí, moralizující vizi, kteroužto by kritický filosof a sociální vědec považoval za slabost. Možná by ji za slabost považovalo i 19. století, které se postupně a ještě nedospěle, o to však vášnivěji a tvrdohlavěji pustilo do poznávání nejrůznějších sfér života a světa bez knuty dříve nedotknutelných náboženských dogmat, to vše na pozadí hroutících se pořádků, donedávna považovaných za trvalé. 19. století se stalo prvním stoletím v historii lidstva, které skutečně systematicky a cílevědomě začalo „vědecky“ poznávat svět. Přestože $\mathrm{v}$ řadě specializovaných vědních oborů zejména $\mathrm{z}$ oblasti přírodních věd lidstvo dosáhlo od Marxových dob pozoruhodných úspěchů, což bylo v souladu s tím, co klasikové marxismu v zásadě předpokládali, když většina „mystiky“ ve stále větší míře ustupovala vědeckým metodám, které si jednotlivé vědní obory postupně vyvinuly na základě těsného sepětí teorie a praxe, v oblasti poznání společnosti a odhadování jejího vývoje zůstávalo a stále zůstává toto poznání omotáno pavučinou ,záhad“ a „mystiky“, byt’ ta již není prvotně odvíjena od náboženství. Celá historie 20. století se dvěma světovými válkami je v podstatě jedním velkým potvrzením, že lidstvo zdaleka kompletně nepoznalo tyto společenské zákony a už vůbec se je nenaučilo používat ke svému „harmonickému vývoji“ a ku prospěchu všech, což koneckonců potvrdil i pád socialistických systémů v Evropě na konci 80.let minulého století. Ale i v oblasti přírodních věd se složitost světa ukázala daleko větší, než si ji materialisté 18. a 19., ale i počáteční bezbřehý optimismus prvních generací budovatelů komunismu stejně jako

\footnotetext{
$2 \mathrm{~K}$ takovým autorům patři například francouzský filosof Louis Althusser, který několikrát změnil interpretaci Marxova díla (v ČJ: Petr KUŽEL, Filosofie Louise Althussera. O filosofiii, která chtěla změnit svět., Praha 2014).

${ }^{3}$ Marxův humanismus a současně kontinuitu Marxova díla zdůrazňuje americký filosof Erich Fromm, když za klíčové téma považuje problematiku odcizení, kterou Marx zachytil především v tak zvaných Ekonomickofilosofických rukopisech (1844). Ty ovšem většině Marxových ortodoxních pokračovatelů dlouhou dobu nebyly známy a poprvé byly publikovány až ve 20. století ( $v$ ČJ např. Erich FROMM, Obraz člověka u Marxe, Brno 2004).
} 
množství optimistických prognóz vycházejících ještě ve druhé polovině 20. století představovali, člověk je stále zranitelný tvor, trpící řadou chorob, závislý na své genetické výbavě, podléhající emocím a často ponižujícím zpưsobem zápasící o holé přežití navzdory ohromnému bohatství v oblasti statků, techniky i vědění, naakumulovaných především za poslední dvě stovky let.

\section{Vývoj ke komunismu}

Marxova metoda poznávání a formulování dosaženého poznání korespondovala $\mathrm{s}$ jeho politickým postojem. Marxův cíl změnit realitu logicky vedl k prvořadé důležitosti, kterou přikládal činu, a tak jeho myšlenkový vývoj byl v nejtěsnější spojitosti s jeho aktivním společenským a politickým působením na veřejnosti. Měnilo se jen to, co v té které etapě považoval za potřebný Čin či Činy. Jedním z nejdůležitějších myšlenkových přerodů byl Marxův posun ke komunismu. K němu pozvolna a opatrně docházelo během první poloviny 40. let, kdy se z revolučního demokrata, který prvořadou pozornost věnoval svobodě slova, ale který psal již i o sociálních otázkách ${ }^{4}$, stává komunista. Ještě v období březen - záŕí 1843 komunismus odmítal jako dogmatickou abstrakci ${ }^{5}$, když klíčovou pozornost podle Marxe bylo třeba věnovat teoretické existenci člověka a předmětem kritiky učinit sféry, které až později začne nazývat „nadstavbou“- náboženství, vědu atd. ${ }^{6}$ V Úvodu ke Kritice Hegelovy fillosofie práva (1843/1844) Marx objevuje třídu, které připadne světodějný úkol pohřbít dosavadní řád. Ve Svaté rodině (září - listopad 1844) ${ }^{7}$, první Marxově a Engelsově společné práci, potvrzují budoucí roli proletariátu při zániku kapitalismu, vyjadřovanou $\mathrm{v}$ hegelovské řeči protikladů: soukromé vlastnictví se svým vlastním ekonomickým pohybem dohání ke svému vlastnímu zrušení, vynáší samo nad sebou rozsudek tím, že plodí proletariát ${ }^{8}$. Marx a Engels zdůrazňují, že proletariát splní to, k čemu ho takříkajíc zplnomocnily dějiny - jestliže proletariát zvítězí, nestane se „absolutní stránkou společnosti“, nebot’ zvítězí jen tím, že „zruší sám sebe i svůj protiklad“", což povede ke zmizení jak proletariátu, tak jeho protikladu - soukromého vlastnictví ${ }^{9}$ Nejde o to, co si ten který proletář nebo dokonce celý proletariát představuje jako cíl, ale o to, co ve shodě se svým společenským bytím bude nucen udělat ${ }^{10}$. Proletariát se tak svým způsobem stává rukojmím Marxovy filosofie, ale současně i tato filosofie zániku kapitalismu riskuje - její uskutečnění doslova visí na tom, zda proletariát svůj úkol pochopí a správně naplní. Tehdy ještě Marx s Engelsem mohli optimisticky konstatovat: „Není třeba šírit

\footnotetext{
${ }^{4}$ Zřejmě nejznámější jsou debaty kolem zákona o krádeži dříví z 18. prosince 1842, poprvé otištěné v čísle 353 „Rheinische Zeitung“ z 19.12. 1842

${ }^{5}$ Tak zejména komunismus je jen dogmatická abstrakce, přičemž nemám na mysli nějaký vymyšlený a možný, nýbrž skutečně existující komunsmus, jak ho hlásají Cabet, Dézamy, Weitling atd. Tento komunismus je jen svérázný projev humanistického prinicpu, infikovaný svým protikladem - privátností. Zrušení soukromého vlastnictví a komunismus rozhodně nejsou totéž, a ne náhodou, nýbrž nutně vznikala současně s komunismem jiná socialistická učení, jako Fourierovo, Proudhonovo atd. - protože komunismus je jen zvláštním, jednostranným uskutečněním socialistického principu. A celý socialistický princip je opět jen jedna stránka, která postihuje realitu pravdivé lidské podstaty. Musíme se stejně zajímat u druhou stránku, o teoretickou existenci člověka, musíme tedy učinit předmětem své kritiky náboženství, vědu atd.“ (Dopisy z „Deutsch-Franzősische Jahrbücher“, září 1843 in: Karel MARX, Bedřich Engels, SPISY sv. 1, Praha 1961, s. 368)

6 Tamtéž.

${ }^{7}$ Prvořadým účelem napsání Svaté rodiny bylo ideově se vypořádat se svými bývalými „kritickými přáteli“, jako byl napríklad Bruno Bauer.

${ }^{8}$ Karel MARX, Bedřich Engels, SPISY sv. 2, Praha 1957, s. 50-51.

9 Tamtéž, s. 51.

10 Tamtéž.
} 
se o tom, že veliká část anglického a francouzského proletariátu si už svou dějinnou úlohu uvědomuje a neustále pracuje na tom, aby toto vědomí nabylo úplné jasnosti."11

Komunistické období není stejnorodé ani z hlediska politického postoje, ani z hlediska základních teoretických problémů, které Marx s Engelsem řeší. Tak zásadní přerod, jaký nastal během první poloviny 40. let, se již nikdy neopakoval. Marx i Engels zůstávají až do smrti komunisty a metodu svého výzkumu a formulování otázek a odpovědí nazývají dialektickým a historickým materialismem. „Jejich“ socialismus, případně komunismus, obhajovaný jejich způsobem argumentace, se stal základem vědeckého komunismu (socialismus), což mělo signalizovat, že všechny jiné typy argumentací jsou nevědecké, a tedy by neměly být brány vážně. Z $Z$ hlediska politického postoje lze v komunistickém období vydělit 1. etapu začínající krátce před polovinou 40. let 19. století a trvající do roku 1848 - v ní jsou navázány těsné kontakty se Svazem komunistů, kdy se Marx s Engelsem stávají jeho hlavními ideology. Z intelektuálního hlediska je tato etapa nesmírně plodná, jsou v ní vypracovány všechny základní principy nové metody poznávání i teze dosaženého poznání, v teoretické rovině má klíčový význam Úvod ke Kritice Hegelovy filosofie práva (1843/1844), Kriticko-filosofické rukopisy (duben-srpen1844), Teze o Feurbachovi (1845) a za vyvrcholení této etapy můžeme pokládat Manifest komunistické strany (prosinec 1847). Druhou etapou je revoluční euforie roku 1848 a následný revolučně-romantický radikalismus, který vydržel do začátku 50. let. Poté nastupuje 3. etapa spočívající v práci na dotváření teorie vědeckého socialismu. Marx s Engelsem působí jako přední teoretici I. Internacionály, angažují se v dělnickém hnutí a čekají na zhroucení kapitalismu, které se oproti dř́vějš́ím předpokladům opozdilo. V intelektuální oblasti je vrcholem tohoto období Kapitál (1. díl vyšel 1867), který demonstroval prioritní význam přikládaný ekonomice. Ve sféře politiky už klasikové marxismu zaujímají mnohem opatrnější př́stup. Po povstání Pařížské komuny (1871) Marx netoužil, třebaže po podepsání příměří Francouzů s Prusy se domníval, že Francie může být zachráněna, pokud pochopí, že k vedení revoluční války jsou nutná revoluční opatření a revoluční energie ${ }^{12}$.

\section{Od kritického idealismu k dialektickému materialismu}

Kriticko-idealistická metoda, kterou Marx uchopoval skutečnost podobně jako řada jeho mladohegelovských souputníků, považovala již samo veřejné a kritické nasvícení skutečnosti za čin, který společnost může významně posunout vpřed - což také v podmínkách, kdy ještě nebyly samozřjejmé některé liberální svobody, skutečně platilo. Marxovo vykázání nejprve z území Německa a poté i z Francie dokázalo, že jeho doba měla vyřčené slovo skutečně ve velké úctě, byt' ta se často projevovala jako strach, bezprostředně ústící do razantní sankce. Marxův ostrý rozum se kriticky zmocňoval problémů a ukazoval absurdity, ke kterým vedou názory jeho odpůrců či př́iznivců starých pořádků ${ }^{13}$. Už v této etapě si Marx všímá vazby mezi různými strukturami společnosti, pozdějším jazykem řečeno mezi ,základnou“ a „,nadstavbou“, byt' v této etapě nelze říci, že by za prvořadou důležitost přikládal práci v „základně“. Filosofova rozumu bylo naopak nejvíce třeba ve sféře, kterou opět pozdějším jazykem nazvěme „falešným vědomím“. Zvláště Němci měli zřejmě touto méně hmatatelnou a viditelnou strukturou svázáni vědomí podle Marxe více než jiní: „Němci vůbec mají sklon k sentimentalitě a exaltaci, rádi se

\footnotetext{
11 Tamtéž.

12 Marx an Lafargue, 4.2. 1871, in: Rolf Hosfeld, Karl Marx. Životopis intelektuála, Praha a Litomyšl 2013, s. 210.

${ }^{13} \mathrm{~V}$ debatách o svobodě tisku: „Tedy především, $k$ do bude udělovat koncesi? Kant by byl neudělil Fichtovi koncesi filosofa, Ptolemaios by byl neudělil Koperníkovi koncesi astronoma, Bernhard de Clairvaux by byl odepřel Lutherovi teologickou koncesi." (Karel MARX, Debaty o svobodě tisku (duben 1942), in: Karel MARX, Bedřich ENGELS, SPISY, sv. 1, Praha, 1961, s. 91).
} 
vznášejí v oblacích. Je proto potěšitelné, demonstruje-li jim někdo velikou otázku ideje z drsného, reálného, z nejbližšího okolí odvozeného ze stanoviska. Němci jsou od př́rody lidé ze všech nejposlušnější, nejpoddanější a nejuctivější. Ze samé úcty $\mathrm{k}$ idejím tyto ideje neuskutečňují. Zasvěcují jim modlářský kult, ale nekultivují je. “14 Německé poměry, ve všech svých sférách, musí být vyvráceny, zničeny ${ }^{15}$ Podstatným patosem kritiky mělo být rozhořčení, její podstatnou prací odhodlání. Klíčové bylo vylíčit tlak všech sociálních sfér na sebe navzájem, všeobecné nečinné rozladění i omezenost, která sama sebe současně uznává i zneuznává. To vše ,zasazeno do rámce vládního systému, který žije jen z toho, že udržuje všechny ubohosti, a sám není nic jiného než vládnoucí ubohost. “16

$\mathrm{V}$ přechodné fázi od idealismu $\mathrm{k}$ materialismu se Marx a Engels rozcházejí se svými mladohegelovskými souputníky. Ti bud' politicky směřují $\mathrm{k}$ anarchismu a myšlenkově křísí Fichteho vůli jedince, jako Bruno Bauer, nebo komunismus a jakýkoliv jiný - ismus odmítají z obecněji formulovaných pohnutek, komunismus si vykládají jako boj proti sobectví, doufají v uskutečnění sociální reformy osvětou, klíčovou metou se pro ně stává humanismus. ${ }^{17} \mathrm{~V}$ článku z roku $1843^{18}$ Engels obhajuje komunismus jako výraz vývoje myšlení, v Německu speciálně filosofie, důsledné a nutné pokračování její radikální formy, jejímž důsledkem byl republikanismus a ateismus. Chválí dílo Proudhonovo „Co je to vlastnictví“ - i s jeho jasnou odpovědí - „vlastnictví je krádež“, věří, že v Německu se rozššří dílo Weitlingovo. ${ }^{19}$ Společně s Mosesem Hessem věří, že mezi německými intelektuály se brzy rozvine komunistické hnutí ${ }^{20}$. Komunismus vidí jako nutný důsledek myšlenkového vývoje v různých zemích, probíhajícího ještě nezávisle na sobě ${ }^{21}$, ale intelektuálně a morálně těžícího z velice bohatých a různorodých zdrojů - od Babeufa přes Saint-Simona a Fouriera až po Cabeta a Proudhona ve Francii, v Německu pak jako nutný vývoj myšlení od Kanta přes Fichta k Hegelovi a mladohegelovcům ${ }^{22}$. Stejně jako Marx v té době považuje soukromé vlastnictví za určující ráz měšstácké společnosti. Komunismus se jeví jako kolektivní vědomí lidstva, ke kterému západní svět postupně dospívá, jako nutný důsledek intelektuálního a etického vývoje, který bude v

\footnotetext{
${ }^{14}$ Karel MARX, Debaty o svobodě tisku, in: Karel MARX, Bedřich ENGELS, SPISY, sv. 1, Praha, 1961, s. 87.

${ }^{15}$ Válku německým poměrům! Ovšemže! Jsou pod úrovní dějin, jsou pod vší kritiku, ale přesto zůstávají předmětem kritiky, jako zločinec, který stojí pod úrovní lidskosti, zůstává předmětem katovým. V boji s nimi není kritika vášní hlavy, je hlavou vášně. Není anatomickým nožem, je zbraní. Její předmět je jejím nepřitelem, kterého nechce vyvrátit, nýbrž zničit. Nebot' duch oněch poměrů je už vyvrácen. Samy o sobě nestojí tyto poměry za přemýšlení, ony jen existují jako něco opovrženíhodného a opovrhovaného. Kritika si už nepotřebuje vyjasňovat svůj poměr $k$ tomuto předmětu, protože je jí jasno, na čem je." (Karel MARX, Úvod ke Kritice Hegelovy filosofie práva, in: Karel MARX, Bedřich Engels, SPISY, sv. 1, Praha 1961, s. 403).
}

${ }^{16}$ Tamtéž, s. 403.

${ }^{17} \mathrm{Na}$ otázku Étienna Cabeta, zda je komunistou, Arnold Ruge odpověděl: „Tato praktická otázka humanismu je nám tak vzdálena, že jsme si ji ani nekladli, říkám 'my' jménem filosofické a politické opozice. $V$ principu jsme však $s$ Vámi zajedno, prohlašujeme jako $V y$ skutečného člověka za princip a účel společnosti, ale ještě nám není jasný způsob, jakým by měla být společnost $k$ tomuto účelu ustavena. Nemůžeme prozatím dělat nic jiného, než aby byl každý jako jednotlivec humánní. Nějaká teorie, jak by bylo možno všechno rázem humanizovat, nám ještě zcela chybí." (Arnold RUGE, Zwei Jahre in Paris I - 1846, in: Auguste CORNU, Karel Marx, Bedřich Engels, Praha 1963, s. 503.

${ }^{18}$ „Úspěchy hnutí za sociální reformu na kontinentě“, vyšel v listopadu 1843 v ústředním listu owenistů „The New Moral World“.

${ }^{19}$ Auguste CORNU, Karel Marx, Bedřich Engels, Praha 1963, s. 561.

${ }^{20}$ Tamtéž, s. 560 .

${ }^{21}$ Tamtéž, s. 561.

${ }^{22}$ „Němci jsou filosofický národ a nevzdají se a nemohou se vzdát komunismu, jakmile spočívá na zdravých filosofických principech - zvláště byl-li odvozen jako nevyhnutelný závěr z jejich vlastní filosofie." (tamtéž, s. 560). 
každé zemi postupovat různým tempem a nejspíš bude mít i poněkud pestrobarevný charakter, tak jak různorodě působí i nejrůznější teoretici a praktici komunismu.

V Tezích o Feurbachovi (1845) Marx předkládá základní rysy svého historického materialismu, který je alternativou k „metafyzickému“ materialismu Feurbachově. Nový „historický“ materialismus musí předmět, smyslovost, skutečnost pojímat nejen ve formě objektů čili nazírání, ale i jako lidskou smyslovou činnost, praxi. Feurbacha Marx kritizuje v řadě bodů vyjadřujících gnozeologické-metodologické principy, které mají závažné společenské implikace: Společenský život je v podstatě praktický, všechna mystéria, která svádějí teorii k mysticismu, jsou racionálně řešena lidskou praxí a chápáním této praxe. Stanovisko starého materialismu je „občanská“ společnost, stanovisko nového materialismu je lidská společnost čili zespolečenštěné lidstvo. Nechybí ani poslední teze, vyjadřující, že smyslem nové fillosofie je změna světa, nejen jeho vykládání jako u starších systémů ${ }^{23}$. Marxových 11 tezí je třeba chápat jako principy, kterých se nový světový názor má držet, $v$ žádném př́ípadě je nemůžeme chápat jako „důkaz jejich pravdivosti“, navíc v případě této filosofie - metodologie, jedním z jejichž bodů je lidská praxe, by nešlo jen o vysvětlení v teoretické rovině, ale muselo by se jednat př́mo o „praktické racionální řešení“ a „chápání této praxe“. Takovýto gigantický úkol Marx nikdy nenaplnil, i když pravděpodobně měl v úmyslu takovýto úkol v nejdůležitějších sférách společnosti, jako je právo, politika či morálka, podstoupit, alespoň v teoretické rovině, když onou praxí by mohl být až nový svět, který vyvstane na odumírajícím světě starém. Nakonec skutečně důkladné teoretické „odmytologizování“ Marx provedl pouze v př́padě buržoazní politické ekonomie a plodem této práce byl Kapitál. Přes řadu důkladných analýz nejrůznějších společenských událostí, jevů a procesů (např. v Engelsově Postavení dělnické tř́́dy v Anglii) perspektiva komunismu na zhrouceném, vyčerpaném kapitalismu zůstávala ideou, která stejně tak jako u všech starších druhů komunismu byla především etickým imperativem, jehož naplnění bylo především věcí víry či vůle.

Marxův a Engelsův nejproslulejší text, Manifest komunistické strany, jednomyslně přijatý komunisty nejrůznějších národností v prosinci 1847 jako oficiální programu Svazu komunistů ${ }^{24}$, představuje konkretizaci Marxových představ o plynutí dějin, v němž ústřední roli hybatelů hrají na jedné straně ekonomická základna kapitalismu a na straně druhé dvě hlavní a protikladné třídy, které kapitalismus porodil. Ukazuje prozatím triumfující a vpravdě revoluční roli buržoazie, která nemilosrdně zničila feudální poměry a ve své honbě za profitem nemůže existovat jinak, jen když neustále revolucionizuje výrobní nástroje, současně tedy výrobní vztahy, současně tedy všechny společenské vztahy ${ }^{25}$ - ale „podobá se kouzelníkovi, neschopnému nadále opanovat tajemné síly, které vyvolal.“26 - a dosud slabého, ale stále sílícího proletariátu, který bude jejím hrobařem. Po vítězné komunistické revoluci, která bude „nejradikálnějším zúčtováním“ $\mathrm{s}$ vlastnickými vztahy ${ }^{27}$, se proletariát stane panující třídou, vydobude demokracii, postupně vyrve buržoazii všechen kapitál, soustředí všechny nástroje v rukou státu a co nejrychleji zvětší množství výrobních sil. Je možné zachytit jen lehký stín váhání nad tím, jak bude fungovat toto zavádění komunismu z politické sféry do ekonomiky, ${ }^{28}$

\footnotetext{
${ }^{23}$ Karel MARX, Teze o Feurbachovi (1945): https://www.marxists.org/cestina/marx-engels/1845/tezefeuerbachovi.htm .

${ }^{24}$ Friedrich Leßner, Erinnerungen eines Arbeiters an Karl Marx. In: Erinnerungen an Karl Marx, Berlin 1953, s.174.

25 Čítanka marxistickej filozofie, zv. 1 K. Marx, F. Engels, Bratislava 1963, s. 17.

26 Tamtéž, s. 19.

27 Tamtéž, s. 32.

28 Tamtéž, s. 32: „Pravda, to se může zpočátku stát jen despotickými zásahy do vlastnického práva a do buržoazních výrobních vztahů, tedy opatřeními, která se zdají hospodářsky nedostatečnými a neudržitelnými, které
} 
nebot' Marx musí vědět, že i proletář, byt' chápající svou světodějnou úlohu a zcela správně teoreticky i prakticky poznávající skutečnost světa i sám sebe, je přece stále jen člověkem ze staré éry. Marx se ve službách komunistického hnutí zpronevěřil své zásadě z kritického období, kdy se vzpíral formulovat nějaké „dogma“. V Manifestu již předkládá soubor opatření, která bude po komunistických revolucích „téměř všeobecně možné“ využít v nejvyspělejších zemích. ${ }^{29}$

Tř́́dní boj se stal významným prvkem cesty ke komunismu, kromě jeho role $\mathrm{v}$ oblasti ekonomických bojů je jeho význam třeba chápat i v rovině emancipačně - etické jako výraz ideologické nezávislosti nové trrídy na „falešném vědomí“" staré společnosti; proletár̆, dosud opovrhovaný člen společnosti stojící na jejím nejnižším stupni, se v Marxově komunismu stává předvojem lidstva, který, třebas nevzdělaný a $\mathrm{v}$ jednotlivých individualitách proletářů trpící nespočtem obyčejných lidských nedokonalostí i špatností, je objektivně připraven tento úkol splnit lépe než všechny ostatní vrstvy tehdejší společnosti, i ty nejvzdělanější či nejvznešenější. Jeho praktickýživot, jeho praktické postavení ve společnosti mu dává vyšší typ poznání, než je teoretické a z valné části mysticismem zastřené vědomí vyšších vrstev, samozřejmě jen pod podmínkou, že proletáři budou mít správné třídní uvědomění a zcela se odstřihnou od „falešného vědomí" buržoazní či dokonce ještě částečně feudální společnosti. Pro revoluční situaci byla na rozdíl od roku 1789 podle Marxe potřebná třída s radikálními okovy, která pro své univerzální utrpení má univerzální charakter, která znamená úplnou ztrátu člověka a která se může emancipovat pouze úplným znovuzískáním člověka, která tedy není ničím a musí být vším. Moderní proletáři se nemohli odvolávat na nějaký historický nárok, ale jen na lidský nárok ${ }^{30}$. Odstřižení proletáře od „falešného vědomí “ buržoazní společnosti praktický třídní boj jednotlivých reálných proletářru neusnadnilo: marxistický komunismus, který byl ateistický a důsledně internacionalistický, je odcizoval od jejich přirozeného etnického a náboženského prostředí, vyšší vrstvy společnosti, které měly nejvyšší ,,sklon k mysticismu“, se od komunisti̊ateistů-materialistů odvracelo. Na druhou stranu marxistický komunismus proletáŕe, kteří mu zachovali věrnost, zocelil, třídní boj také nebyl žádný Marxův vynález, viděl ho v realitě a s obdivem o jeho aktérech hovořil ještě dříve, než jeho filosofie dostala pevné obrysy.

\section{Latentní idealismus a kontinuita kriticismu}

Dialekticko-historicko materialistická fáze Marxova myšlení se tematicky zabývá stejným problémem jako jeho fáze idealisticko-kritická, je specifickou formou její konkretizace. Za kompas, který ukazuje směr Marxova myšlenkového směřování, poslouží již Marxova doktorská disertační práce ${ }^{31}$, kde na pozadí výzkumu názorů řeckých filosofických škol epikurejců, stoiků a skeptiků zkoumal vztah filosofie ke světu a upřednostnil jako vyšší ideovou a mravní pozici názory ateisty Epikura jak proti povrchnímu náboženskému a moralizujícímu filosofování Plutarcha, tak proti materialistickému deterministovi Demokritovi, kterého postoj Epikurův převyšuje zase ve víře ve svobodu, kterou disponuje základní prvek hmoty, atom, který je současně živý a uvědomělý ${ }^{32}$. Marx formuloval zákonitost vztahu mezi filosofií a

\footnotetext{
však v průběhu hnutí přerostou samy sebe a jsou nevyhnutelná jako prostředek na dosažení převratu v celém způsobu výroby. Pravda, tato opatření budou v různých zemích různá.".

29 Tamtéž, s. 32.

${ }^{30}$ Karel MARX, Úvod ke kritice Hegelovy filosofie práva, Karel MARX, Bedřich ENGELS, SPISY sv. 1, Praha 1961, S. 413.

${ }^{31}$ Marxovy práce na ní započaly v létě v létě 1839.

32 Auguste CORNU: Karel Marx, Bedřich Engels, Praha 1963, s. 183-184.
} 
světem, kterou můžeme chápat jako hlubší odůvodnění toho, oč chtěl usilovat svým dílem - v dějinách světa podle Marxe, který byl tehdy ještě hegelovec, nastávají okamžiky, kdy konkrétní stav světa odpovídá rozumu, a filosofie se tak stává konkrétní totalitou, ale tato jednota se jindy narušuje roztržkou mezi rozumným a skutečným ${ }^{33}$. Filosofie se pak stává abstraktní totalitou, a svět iracionálním ${ }^{34}$. Z tohoto pohledu pak první fázi Marxova díla, kdy je kritickým idealistou s důrazem na filosofii činu, jak to bylo typické pro mladohegelovce, můžeme chápat jako hledání pravdy - filosofie - vědy pro skutečnost světa, přesněji pro změnu této skutečnosti, zatímco období po zformulování základních stavebních kamenů této nové pravdy - filosofie vědy je obdobím, kdy svět musí „pochopit“, „uvědomit si“ tuto pravdu a kdy nastane jednota vědění a skutečnosti. To přirozeně neodvisí od stavu uvědomění a pochopení toho kterého jednotlivého individua, jehož myšlení koneckonců určují daleko významnější struktury, které jeho individuální mysl odráží. O správné uvědomění světa usiluje v první fázi fillosof, který na jeho základě formuluje teorii a praxi, o jejíž pochopení a realizaci světem jde zase ve druhé fázi. Zásadní epistemologické principy Marx formuloval ve své idealistiko-kritické fázi, jeho pozdější fáze je subjektivně jejich konkrétním naplněním.

Marxem a Engelsem provedená transformace komunistické myšlenky ji obohatila o analýzu fungování kapitalistické společnosti a nastolila problém vztahu mezi vědomím společnosti a jejími sociálními a ekonomickými strukturami, ale v oblasti přechodu ke komunistické společnosti nemohla představit nic jiného než předpoklad, který se ovšem Marxovi a jeho stoupencům jevil jako zákon dějin. $\mathrm{V}$ textech pojednávajících o „nutném“ přechodu od kapitalismu ke komunismu je nápadný nepoměr mezi extenzivně pojatou analýzou struktur kapitalismu, které jsou ve vztahu rozporů, a stručném vyvrcholení, kterým se tyto rozpory měly vyřešit. V 80. letech 19. století Engels vidí souběžnou tendenci vývoje kapitalismu, „který stále naléhavěji vyžaduje přeměnu velkých zespolečenštěných výrobních prostředků ve státní vlastnictvi““ a revoluční akcí proletariátu, který „se chápe státní moci a mění výrobní prostředky nejprve ve státní vlastnictví. Ale tím ruší sám sebe jako proletariát, tím ruší všechny třídní rozdíly a protiklady, a tím i stát jako stát." Jakmile už není tř́da, kterou by bylo třeba potlačovat, jakmile jsou spolu s třídním panstvím a s bojem o individuální existenci odstraněny i kolize a výstř̌elky výroby vyplývající z dosavadní anarchie výroby, není nic, co by vyžadovalo zvláštní potlačovací moc, stát. Zasahování státní moci do vztahů ve společnosti už se stává zbytečným v jedné oblasti po druhé, postupně samo usíná. „Stát odumírá،“" ${ }^{35}$ Tato vize tedy představovala ideu-ideál, který se měl kdysi v budoucnu naplnit. Marxovo postavení otázky komunismu jakožto „zákonitosti překonání kapitalismu“ muselo mít velký psychologický efekt, který se za určitých okolností mohl „materializovat“ v dějinách. Realizace komunistického ideálu byla pevně spojena s představou odstranění nadvlády ekonomické nutnosti nad lidskou společností a společnosti, kde se již nebudou projevovat staré modely chování lidí založené na nepřátelství a konkurenci i z jiných než čistě ekonomických motivů, byt' ony ekonomické, což byla nepochybně pravda, jsou těmi nejobvyklejšímu motivy bojů a válek mezi lidmi, národy, ř́šemi. Jen $\mathrm{v}$ takovém velmi utopickém případě bychom mohli uvažovat o tom, že nebude zapotřebí

\footnotetext{
33 Tamtéž, s. 187.

34 Tamtéž, s. 187: „Jako jsou ve filosofii uzlové body, které se samy v sobě povznášejí ke konkreci, shrnují abstraktní principy v jedinou totalitu, a tak přerušuji pokračování přímky, tak jsou i momenty, v nichž obrací filosofie svůj zrak do vnějšího světa, a nikoli již jako vnímající, nýbrž jako praktická osoba spřádá intriky se světem...Tak se obrací filosofie, která se rozširíila ve svět, proti jevícímu se světu... Svět je nyní rozpolcen a vykročil tváří v tvář filosofii, jež je $v$ sobě totální. Jev činnosti této filosofie je tím také rozpolcený a protikladný; její objektivní všeobecnost se převrací v subjektivní formy jednotlivého vědomí, v nichž je živá.“
}

${ }^{35}$ Bedřich ENGELS, Vývoj socialismu od utopie k vědě, část III Historický materialismus (1880), Online Version: Marx/Engels Archive (marxists.org) 2010: https://www.marxists.org/cestina/marx-engels/1880/soc-utop/ch03.htm 
stát jakožto svými občany uznávaná autorita sloužící $\mathrm{k}$ řešení nejrůznějších rozporů ve společnosti.

Jak ale bude vypadat skutečný přechod od kapitalismu k jinému systému? Marx za svého života zažil skutečnou revoluční euforii jen v roce 1848 a také vykrvácení revoluce, kdy generál Cavaignac reprezentující novou buržoazní moc nastoupivší po červencové revoluci (1848) ve Francii postupoval proti pařǐžským dělníkům s tvrdostí, kterou si představitelé a generálové feudálního habsburského státu proti rebelům v Čechách nebo severní Itálii naprosto nedovolili. $\mathrm{V}$ následujícím období teoretického radikalismu, kdy se Marx nechtěl smířit s porážkou revoluce, Marx volá po světové válce proti Rusku jakožto centru evropské rakce ${ }^{36}$ a revolučnímu terorismu. ${ }^{37}$ Engels, osobně se podílející na jihoněmeckém povstání, se rozhořčuje nad „Slovany zrazujícími revoluci. “ 38 a Marx s Engelsem se najednou projevují jako Velkoněmci, kterým náhle záleželo na tom, kam až sahají hranice jejich státu, a po vzoru Hegela rozdělují národy na národy dějinné a národy bez dějin, které nemohou prokázat žádný pohyb a vývoj ${ }^{39}$. V dubnu 1850 Marx zakládá Světovou společnost revolučních komunistů, která chce svržení všech privilegovaných tříd, diktaturu proletariátu a permanentní revoluci, na někdejší Svaz komunistů pohlíží jako na zdroj kádrů a na dělníky je pohlíženo jako na svébytný element revolučních dějů: „Dělníci ...musejí pracovat na tom, aby bezprostřední revoluční chaos nebyl ihned po vítězství zase utišen. Naopak jej musejí udržovat tak dlouho, jak jen bude možné. V žádném případě nesmějí zabraňovat takzvaným excesům, př́íkladům lidové msty na nenáviděných individuích nebo veřejných budovách, $\mathrm{k}$ nimž se vážou nenávistné vzpomínky. Tyto exemplární činy je třeba nejen strpět, nýbrž je vhodné vzít jejich provádění do vlastních rukou." $" 40$

Čteme-li tyto řádky, do mysli vstupují události z jiné, již uskutečněné revoluce pod vedením Lenina v Rusku 1917 a všech dalších úspěšných komunistických revolucí, pro něž rozhodujícími faktory byla revoluční energie a odhodlání $\mathrm{k}$ násilí, které jediné jim mohly pomoci přehoupnout se přes horizont starého společenského systému. Marx s Engelsem, kteří na vlastní kůži zakusili komplexní působení nejrůznějších společenských a ideových struktur při revoluci, nakonec žádné důkladnější zpracování tohoto tématu neučinili. V podmínkách nejistoty a rizika ztráty života, které nutně v revolučních situacích musely nastat, je přirozeně jediným motorem činu a vůle k činu idealismus, který se nedá nahradit žádným ,racionálním poznáním“. Idealismus je tudíž implicitní podmínkou i té verze marxistického komunismu, která byla formulována $\mathrm{v}$ dialekticko-historicko materialistické formě. Ukrývá se ve formulích třídního boje a revoluce. Revoluce (Velká francouzská 1789) se již prakticky osvědčila, třebaže prozatím na piedestal dějin vyzdvihla třídu dosud strádající svým sobectvím a nereprezentující zájem lidí jako takových. Tř́́dní boj Marx artikuloval až v jeho komunistické a dialektickohistoricko materialistické fázi, ale byl jen pokračováním a přenesením do materiálních podmínek jeho předchozího intelektuálního boje, který Marx podstupoval ve své idealistikokritické fázi. Žádný akt ve světě, který směřuje k jeho radikální změně, nemůže být vykonán bez idealistického přesvědčení. O výsledcích tohoto aktu nelze dopředu říci nic jistého, žádná

\footnotetext{
36 Tamtéž, s. 142.

37 Sieg der Kontrarevolution zu Wien, „Neue Rheinische Zeitung!, 7.11.1848, in: Rolf Hosfeld, Karl Marx. Životopis intelektuála, Praha 2013, s. 143.

38 Tamtéž, str. 147.

${ }^{39}$ Fridrich HEGEL, Vorlesungen über die Philosophie der geschichte, in: Rolf Hosfeld, Karl Marx. Životopis intelektuála, Praha 2013, s. 146.
}

${ }^{40}$ Karel MARX, Bedřich ENGELS, Ansprache der Zentralbehörde an den Bund vom März 1850, in: Rolf Hosfeld, Karl Marx. Životopis intelektuála, Praha 2013, s. 156. 
„teorie“ nezaručuje, že aktivní subjekt historie má jistotu, že „objektivní faktory“ jsou tomuto aktu nakloněny. Boj je podstupovaný kvůli ideálu, kterým je komunistická budoucnost, a principem pohánějícím aktivitu subjektu dějin je idealismus.

Na pozadí Marxovy teorie třídního boje se rýsuje starší Hegelův idealistický systém, kdy střetáváním protikladů se ve světě vytváǎí vyšší stav bytí-myšlení. Marxův třídní boj je tak první konkretizací Hegelových protikladů, ztělesňujících nejen nejabstraktnější boj myšlenek, ale i ten nejpřízemnější, nejhmatatelnější a nejkrvavější boj ve zcela konkrétních a hmatatelných společenských podmínkách, v konkrétní socio-ekonomické sféře, kdy boj koneckonců poslouží přechodu světa a jeho myšlení na vyšší kvalitu. Na Darwinovu vývojovou teorii člověka můžeme nahližet jako na druhou konkretizaci Hegelovy filosofie, tentokrát do oblasti biologických zákonitostí: také zde je hlavní pákou biologického pokroku boj - tentokrát nikoli třídní, nýbrž boj druhů o přežití, který je ve své podstatě jen vyjádřením stejné charakteristiky světa na nižší úrovni. 19. století ale Darwinovu teorii chápalo jako na potvrzení kapitalistického statusu quo, kdy lidé spolu ekonomickými prostředky bojují, konkurují si a v tomto boji přežívají ti dokonalejší, lépe přizpůsobení. Zatímco Marx Darwinovu teorii přivítal, protože strhávala „mystický prvek“ z tak zásadního světového procesu, jakým byl vznik lidské bytosti, a potvrzovala tak jeho materialistickou filosofii, Darwin se marxistou rozhodně nestal ${ }^{41}$.

Marxova vize komunismu je pozoruhodně chudá na úvahy týkající se psychologie, sociologie a politiky budoucí společnosti, ostře odmítá takové vize komunismu, jako bylo dílo francouzského filosofa Étienna Cabeta Cesta do Ikárie ${ }^{42}$, které si ve své době získalo statisíce čtenářů a které zobrazovalo Ikárii jako zemi, kde demokraticky volená vláda kontroluje veškerý ekonomický, ale i sociální život. Úspěch knihy podnítil Cabeta k tomu, aby se svou Ikárii pokoušel uskutečnit na malých komunitách v praxi, založil komunitární sociální hnutí, pro které vynalezl i nové slovo - komunismus. Cabet spojoval myšlenku komunismu s křest’anstvím. Ve své knize „Skutečné křest’anství podle Ježíše Krista“ v pěti svazcích (1840) vyslovuje tezi, že království Boží oznámené Ježíšem Kristem nebylo ničím jiným než komunistickou společnostít ${ }^{43}$. To, že některé ideje, jako byla idea komunismu, nejsou př́liš závislé na „stupni výrobních sil“", svědčí i ideální model společnosti zobrazený řeckým fillosofem Platónem. Společnost je v něm rozdělena na dvě základní skupiny - pracující na jedné a na strážce a vládce na druhé straně; vzhledem k nárokům, jaké jsou kladeny na jejich vzdělání, schopnosti a dovednosti, Platon předpokládá, že obě skupiny se liší povahou své duše ${ }^{44}$. Omezení vlastnictví se v Platonově státě vztahuje především na strážce a vládce - jejich existence je organizována na základě rovnosti, solidarity a kolektivismu, jejich potřeby jsou uspokojovány státem, aby se mohli plně věnovat svým funkcím, Platon zde nezapomněl ani na takové potřeby, jako je jejich ubytování a společné stravování. Později Platon dospívá k názoru, že vlastnická omezení by se měla vztahovat i na třídu pracujících. ${ }^{45}$ Platon věnuje i podstatný prostor tomu, jak mají být lidé v Platonově státu vychováváni: výchovné programy trvají do 20 . roku věku, ti nejlepší pak získají možnost dalšího včetně filosofického 15 . letého vzdělání, ale ve 35 letech končí teprve

\footnotetext{
${ }^{41}$ Po vyjití Kapitálu Marx Darwinovi zaslat výtisk svého díla, Darwin ho ovšem odmítl přijmout.

42 „Cesta a dobrodružství lorda Williama Carisdalla do Ikárie“ (1840).

43 Paul BÉNICHOU, Le Sacre de l'écrivain : Doctrines de l'âge romantique, Paris 1977, s. 402 n. 63.

44 PLATON, Ústava, Bratislava, 1980, 412 D, s. 149.

45 PLATON, Zákony, in: Milan LUPTÁK, Vladimír PROROK, Politické ideologie a teorie. Od starověku po rok 1848 , Plzeň 2011, s. 115.
} 
jejich teoretické vzdělání, zatímco praktické schopnosti si osvojí až v dalších 15 letech, kdy mohou nastoupit na místa vládců ${ }^{46}$.

Podrobnějšími představami o budoucí společnosti se zabývali také Marxovi bezprostřední předchůdci, ale i současníci, jako byl Pierre-Joseph Proudhon, Charles Fourier, Robert Owen, Henri de Saint-Simon. Charles Fourier rozpracoval myšlenku, jak transformovat práci do potěšení, která se stala ústředním problémem zase jeho verze ideální společnosti. Věřil, že existuje 12 běžných vášní, které vytvářejí 810 typů charakterů, tedy jeho ideální falangy musejí mít 1620 osob, počítáme-li muže a ženy. Tyto volně řízené falangy by řídil světový „omniarcha“, kterého v jeho představách později vystř́idal Světový kongres falang ${ }^{47}$. Fourier dobovou civilizační výchovu obviňuje z potlačování a deformací schopnosti dítěte a vytváření odporu k práci. Harmonická výchova by měla být orientována na přednost praxe před teorií a využití pobídek vášní, které by bylo opakem donucování a povinnosti. Výchova podle Fouriera byla po obživě tou nejdůležitější potřebou člověka. Jelikož myšlenka komunismu původně přichází ze sféry etiky, zdá se být přirozené, že při udržení takovéto etické společnosti bude muset být mimořádný důraz kladen na výchovu a vzdělání.

Marx prakticky žádnou z důmyslných konstrukcí a nápadů těchto myslitelů nevyužil, třebaže se zjevně o žádné bezbřehé a nerealistické fantazírování nejednalo. Cenil si dílo těchto myslitelů, ale celou řadu konkrétních myšlenek tak zvaných utopistů odmítl proto, že zavrhovali třídní boj. Význam kriticko-utopického socialismu byl podle něj nepř́mo úměrný historickému vývoji. „Tou stejnou mírou, jak se vyvíjí a utváŕí třídní boj, ztrácí toto fantastické povznášení se nad něj, toto blouznivé potírání trrídního boje jakoukoliv praktickou cenu, jakékoliv teoretické oprávnění. “48 Osudy a průběh reálného socialismu v řadě případů, třebaže živelně a metodou pokusu a omylu, potvrzovalo reálnost problémů, na které poukazovali tak zvaní utopisté, a které bychom mohli vyjádřit jako problém formování adekvátního vědomí a adekvátních politických, sociálních a snad i kulturních struktur komunismu a socialismu. Marx si ve své kriticko-idealistické fázi vytyčil úkol zbavit společnost „falešného vědomí“, odstranit všechny represivní struktury, které člověku brání překonat nejrůznější druhy odcizení. Důraz na morálku a etiku Marxovi připadal př́liš závislý na „dobré vůli““ vládnoucích vrstev společnosti. Marx odmítl konstruovat novou společnost ze sféry nadstavby, o budoucí komunistické společnosti načrtl jen základní schéma, veškeré podrobnosti organizace a ideologie společnosti nejspíš měla vyřešit až tato budoucí společnost. Ve své třetí tezi o Feurbachovi relativizuje úsilí myslitelů prostřednictvím výchovy a okolností změnit lidi, když sám vychovatel je produktem okolností a výchovy a musí být vychováván ${ }^{49}$. Marxovi neimponovaly nejrůznější více méně promyšlené projekty tak zvaných utopistů, $\mathrm{k}$ problému socialismu a komunismu chtěl přistoupit jako filosof. Můžeme spekulovat, že i Marxova komunistická budoucnost by měla být složena $\mathrm{z}$ altruistů, cesta k takovému stavu však logicky musela být dlouhá a plná nástrah, obzvlášt' když na její trajektorii se společnost měla dostat prostřednictvím třídního boje a revolučního násilí. Tak jako Marx kriticky přistoupil ke strukturám buržoazního vědomí, zejména $\mathrm{k}$ náboženství, kriticky uchopil i všechny verze socialismu, které se lišily od té jeho, obzvláště pak ty, které na rozdíl od něj přímo z některých

\footnotetext{
${ }^{46}$ Milan LUPTÁK, Vladimír PROROK, Politické ideologie a teorie. Od starověku po rok 1848, Plzeň 2011, s. 115.

47 Jonathan BEECHER; Richard BIENVENU (eds.), The Utopian Vision of Charles Fourier Selected Texts on Work, Love and Passionate Attraction, USA 1983, s. 220.

${ }^{48}$ Karel MARX, Bedřich ENGELS, Manifest komunistické strany, in: Čítanka marxistickej filozofie, zv. 1 K. Marx, B. Engels,Bratislava 1963 s. 42.

${ }^{49}$ Karel MARX, Teze o Feurbachovi (1945): https://www.marxists.org/cestina/marx-engels/1845/tezefeuerbachovi.htm .
} 
takových buržoazních či dokonce předburžoazních struktur vědomí vycházely. Marx proto podrobil kritice všechny verze socialismu, vytvářené jeho současníky, které vycházely z jiných filosofických pozic nebo se ostentativně k žádné filosofické pozici nehlásily.

Se svým současníkem, Pierre-Josephem Proudhonem, anarchistou, který anarchii vyjádřil jako pořádek bez moci a také zcela odmítal soukromé vlastnictví, Marxe zprvu pojily sympatie. Když v roce 1846 Proudhon odmítá Marxovu nabídku na spolupráci v zájmu odstranění názorových rozdílů při budování jedné bezpartijní kritiky, kterou by prezentoval Svaz komunisti̊, slovy - „Hledejme, chcete-li, společně zákon společnosti, ale vyhněme se proboha snu o tom, že až odstraníme všechny apriorní dogmatismy, naoktrojujeme lidem své mínění‘50 - podrobil i Proudhonovu filosofii zdrcující kritice. ${ }^{51}$ Text knihy Marx zakončuje rezolutním zvoláním, vyjadřujícím jeho nezrušitelnou jistotu, na čem závisí konec kapitalismu: „Dělnická třída nahradí během svého vývoje starou buržoazní společnost asociací, která vylučuje třídy a jejich antagonismus, a nebude již politické moci ve vlastním smyslu, protože právě politická moc je oficiálním výrazem trrídního antagonismu uvnitř občanské společnosti. Do té doby bude antagonismus mezi proletariátem a buržoazií boj tř́idy proti třídě, boj, který přiveden ke svému nejvyššímu výrazu znamená totální revoluci. Můžeme se ostatně divit, že společnost, založená na protikladu tříd, vyústí v brutální rozpor, ve stř̌etnutí muže proti muži jakožto poslední řešení? Neř́kejte, že společenský pohyb vylučuje politický pohyb. Nikdy neexistuje politický pohyb, který by nebyl zároveň společenským pohybem. Jedině za takového pořádku, v němž už nebude tříd a třídního antagonismu, přestanou být společenské evoluce politickými revolucemi. Do té doby bude poslední slovo vědy o společnosti v předvečer každého všeobecného přetvoření společnosti znít: ' Boj nebo smrt. Krvavá bitva nebo nebytí. Tak neúprosně je položena otázka (George Sand) ${ }^{\prime c 52}$

Boj je nejradikálnější formou kritiky společnosti, kterou Marx vedl prostřednictvím filosofie již dlouhá léta. Výše uvedená formulace je jen konkretizací a zúžením totálního boje, který Marx ve svém Úvodu ke kritice Hegelovy ${ }^{53}$ vyhlásil celému Německu: „Jediné prakticky možné osvobození Německa je osvobození z pozic té teorie, která prohlašuje člověka za nejvyšší podstatu člověka. Německo se může emancipovat od středověku jen tak, že se zároveň emancipuje od všeho částečného překonání středověku. Německo nemůže svrhnout žádnýdruh poroby, nesvrhne-li porobu všeho druhu. Důkladné Německo nemůže dělat revoluci jinak než důkladně. Emancipace Němce je emancipace člověka. Hlavou této emancipace je filosofie, srdcem je proletariát. Filosofie se nemůže uskutečnit bez zrušení proletariátu, proletariát se nemůže zrušit bez uskutečnění filosofie. “54

Marxova nesmiřitelná pozice ke všem odlišným odrůdám socialismu nutně vedla $\mathrm{k}$ tomu, že samotný marxismus se pro mnohé stával nekritizovatelným idolem, projevujícím se následnými boji o to, kdo je věrným a nevěrným Marxovým pokračovatelem. Marxismus nabývá i podoby víry $\mathrm{v}$ jedinou správnou cestu historie, odchýlení od níž se trestá zavržením. Strohým vyobrazením budoucího komunismu, zato plným soustředěním na právě probíhající boj, kterému je třeba podřídit a obětovat vše, nebot' jen takový boj má také nejvyšší morální hodnotu, jakoby marxismus měl strach z toho, že „fantazírování“ své stoupence odvede od splnění světodějného úkolu. Tato strohost ve vyobrazení budoucnosti, třebaže vše se v jejím

\footnotetext{
50 David MCLELLAN, Karl Marx. Leben und Werk, München 1974, s. 115.

51 V knize Bída filosofie (1847).

52 Karel MARX, Bída filosofie: http://www.kmbe.cz/BidaFilosofieFinal.pdf, s. 94.

53 Prosinec 1843 - leden 1844.

${ }^{54}$ Karel MARX, Úvod ke kritice Hegelovy filosofie práva, in K. Marx, B. Engels, SPISY sv. 1, Praha 1961, s. 414.
} 
jménu konalo, se podobala odporu některých náboženství k vyslovování církví neautorizovaných soudů o Bohu, zákazu opěvovat Boha jinými než posvátnými jazyky, ${ }^{55}$ nepřípustností vyslovovat Boží jméno, zobrazovat Boha, když pohlédnutí do Boží tváŕe by pozemského smrtelníka ihned usmrtilo. Marx se nezabýval psychologií lidí, kteří revoluci provedou, ani psychologickými, sociologickými a politickými otázkami budoucího komunismu, protože v centru jeho filosofie není nějaký konkrétní lidský jedinec, ale „lidská podstata“, „lidství“, „skutečný člověk“, „lidský druh“, tedy to, co všichni lidé mají společné a co je pro jejich charakteristiku nejpodstatnější, a právě o osvobozování a naplňování tohoto jejich ,skutečného lidství“ $v$ historii jde.

Revoluci a komunismus ale neprováděla „lidská podstata“, ale jednotliví lidé se všemi svými slabostmi a strastmi. Marx, zaujatý osvobozením člověka, jej na rozdíl od křest'anství zbavil „dědičného hříchu“, a tak mu otevřel velkolepou budoucnost už zde na zemi, třebaže v praktické rovině před společností odhodlavší se budovat komunismus čekaly problémy, na které jim marxismus nedával odpověd'. Jaké ideály, hodnoty nebo snad víru měla a mohla mít společnost směřující ke komunismu? Marxismus se svým vědeckým komunismem ideály, o nichž se píše již v Bibli, formuloval v jazyku vědy, nutnosti a racionality, přesto mírou jeho uskutečňování zůstávala vždy etika a humánnost, kterou se řídila společnost a vztahy mezi lidmi. Marx na ideové struktury staré společnosti pohlížel jako na překážku na cestě ke komunismu, nebral v potaz variantu, že může docházet $\mathrm{k}$ jejich koexistenci se socialistickým a komunistickým vědomím společnosti, dokonce se můžou navzájem podporovat.

Druhou dialekticko-historicko materialistickou fázi Marxova myšlení spojuje s první kritickou fází racionalismus. Racionalismus ve smyslu schopnosti odhalit struktury v oblasti materiální i ideové, které brání „lidské svobodě“, jsou zdrojem „odcizení“ člověka od sebe samého apod. I racionalismus ve smyslu vytváření představy o tom, kam by svět a společnost měly směřovat i konstruování jakýchkoli předpovědí o budoucím vývoji. Tyto představy i konstrukce budoucnosti jsou jen systémem idejí, byt' autorova snaha o „objektivizaci“ těchto idejí ve smyslu co nejplnějšího, nejvědečtějšího a nejpoctivějšího uchopení „reálné skutečnosti“může být sebevětší. Marxův důraz na praxi, která má být spojnicí mezi těmito idejemi a realitou, je přirozený, nicméně postulace praxe jakožto klíčového prvku v epistemologickém procesu sama o sobě žádné ex ante myšlenkové konstrukci ,potvrzení“ praxe nezaručuje, byt' autor idejí se je snaží zkonstruovat na základě domnělých ,zákonů dějin“. Dokud přechod od kapitalismu k socialismu nenastane, ideje popisující tento přechod i to, že k němu dojde, jsou jen idejemi. Dokonce i kdyby k tomuto přechodu došlo podle ex ante vyslovených konstrukcí, automaticky by to neznamenalo, že i příciny, proč tomu tak bylo, byly shodné s těmito ex ante představami - nesmírně komplexní charakter sociálních jevů a skutečnost, že historické události obvykle mají charakter unikátních, neopakovatelných a neopakovaných jevů a procesů, ale i skutečnost, že lidstvo žádné ,jisté“ zákony svého rozvoje nemá, nikdy neumožňuje ze hry vyloučit „náhodu“ či nějaký „,specifický faktor“ anebo dokonce „neznámý faktor“. Vůbec nejde na tomto místě o kritiku Marxe za to, že nějaké prognózy vyslovil či že nějaké racionální konstrukce o skutečnosti prováděl, to je podstata každého a celého lidského poznávání, každé teoretické i praktické činnosti člověka, každé vědy (a vlastně právě ve vyslovení těchto předpovědí vidíme největší př́nos Marxe), nejde ani o to, nakolik se jeho předpovědi a jeho konstrukce skutečnosti blíži této skutečnosti (bez ohledu na to, že kapitalismus přetrval, Marxovy vhledy do skutečnosti považujeme za mnohem věrnější této skutečosti než např́iklad vhledy tak zvané liberální ekonomie, o mnohem větší etické hodnotě marxismu ani nemluvě,

\footnotetext{
${ }^{55}$ Například v křest’anství církevní liturgie mohla dlouhou dobu probíhat jen ve třech jazycích - latině, rečtině a hebrejštině.
} 
byt' marxismus sám nechtěl být nějakou „etickou soustavou“), jde o to, zda na dějiny můžeme nazírat pouze jako na „materiální “ proces, když samo myšlení člověka, konstruování představ o tomto světě a o jeho budoucnosti, a je jedno, zda se jedná o ty „nejmystičtější“ představy nebo nejvědečtější a nejexaktnější metody poznání podle „nejmodernějších“ poznatků, k jejichž dosažení bylo případně použito „nejmodernější“ techniky, počítačů atd., ale nejen myšlení, i etika člověka, jeho estetika, celé kulturní dědictví, které si nese sebou a uvnitř sebe, jeho vůli i ideály a ideje, ke kterým v ten který okamžik vzhlíží, je něčím, co si zařazení do kolonky „materiální“ rozhodně nezaslouží. Dialekticko-historičtí materialisté (a spolu s nimi v jejich době i značná část kulturní i vědecké elity) odmítali jako „mystiku“ zejména náboženství v tom smyslu, že je to klam, který brzdí poznání lidstva, ale neuvědomili si, že i jejich systém myšlenek je jen systémem idejí, byt' pracující jinou metodou, vytyčující si jiná témata a cíle, snaží se být „objektivní“, „vědečtí“. I kdybychom připustili, že jednou bude existovat takové lidstvo, které bude moci s absolutní přesností předvídat či konstruovat vlastní budoucnost, a bude to provádět na základě naprosto exaktních a nejmodernější vědou a technikou dosažitelných metod poznání bez sebemenší „mystiky“, čímž můžeme myslet třeba prvek náhodnosti či omylu či neznáma, žádný takový pohyb dějinami by nebylo možné nahlížet jako pohyb na základě čistě ,materiálních“ faktorů, když naopak právě onen lidský rozum nebo dokonce Rozum lidstva by v něm hrál naprosto základní úlohu.

Co je to vlastně rozum? Intelektuální schopnost poznávat svět, tedy formulovat adekvátní teorie o světě, které při střetu s realitou a odhalením, uvědoměním si „,nesouladu“ vyměníme za jiné? Je tu otázka, za jakým účelem tyto teorie vytváříme - za čistě praktickým, nutností přežít nebo nějakým teoretickým, či to vše je neoddělitelné od toho, co můžeme nazvat „moudrostíi“, pochopením řádu věcí, „smířením se světem“ nebo dokonce pochopením „velkoleposti světa“, od čehož je už jen malý krůček k tomu, abychom oslavovali „Tvůrce“ a „Pána světa“ a „našeho Stvořitele“? Mezi náboženstvím a utilitaristickým, pragmatickým nebo zase teoretickým poznáním neleží nepřekročitelný oceán. Marx ve svém kriticko-idealistickém období optimisticky napsal: „Rozum existoval vždy, jenže ne vždy v rozumné formě. Kritik tedy může navázat na jakoukoli formu teoretického a praktického vědomí a vyvodit $\mathrm{z}$ jeho vlastních forem existující skutečnosti pravdivou skutečnost jako to, čím má skutečnost být, a jako její konečný účel." “56 Jak kritik ví, že vyvodil „pravdivou skutečnost“"? Řada formulací Marxe z jeho kriticko-idealistické fáze není př̀voditelná na formulace $\mathrm{v}$ jeho dialekticko-historicko materialistické fázi, myšlenky z jeho dialekticko-historicko materialistické fáze zato většinou můžeme chápat jako konkretizaci, splnění úkolu, který si zadal v období prvním. Marx chce vyvodit světu principy z principů vlastních světu. „Neříkáme světu: přestaň bojovat, celý tvůj boj je nesmysl; my ti dáme to pravé bojové heslo. My jen světu ukazujeme, zač vlastně bojuje, a vědomí je věc, kterou si svět musí osvojit, i kdyby nechtěl. “" ${ }^{\text {57 }}$ Marx věří, že po reformě vědomí ne pomocí dogmat, ale prostřednictvím rozboru mystického, sobě samému nejasného vědomí, „se ukáže, že svět už dávno sní o věci, kterou si potřebuje jen uvědomit, aby se jí opravdu zmocnil. Ukáže se, že nejde o to udělat tlustou čáru mezi minulostí a budoucností, nýbrž o uskutečnění myšlenek minulosti. A konečně se ukáže, že lidstvo nezačíná novou práci, nýbrž vědomě uskutečňuje svou starou práci. “58

\footnotetext{
${ }^{56}$ Karel MARX, Dopisy z „Deutsch-französische Jahrbücher“, in: Karel MARX, Bedřich ENGELS, SPISY sv. 1, s. 368.

57 Tamtéž, s. 369.

58 Tamtéž, s. 370.
} 
Jakkoliv je třeba největší opatrnosti při formulování nějakých ,zákonů dějin“, nelze považovat za náhodu, že komunismus na sebe $\mathrm{v}$ historii někdy bral rysy připomínající náboženskou víru a takováto nepochybující víra se často také vyžadovala. Oba klasikové, Marx s Engelsem, a všichni jejich hlavní pokračovatelé odmítali idealistickou filosofii především z toho důvodu, že tehdejší náboženství, nejviditelnější bašta idealistické představy o světě, bylo apologetikou tehdejšího společenského uspořádání, a právě proto si nepřipouštěli ani stín pochyb o nesprávnosti takovýchto nábožensko-filosoficko-ideologických postojü ${ }^{59}$. Komunismus, i ten po „zvědečtění“, který provedli Marx s Engelsem, obsahoval dva předpoklady, totiž jednak že skutečně lidská společnost bez vykořist'ování člověka člověkem je vůbec možná, a za druhé že skutečná, pravá podstata člověka je člověk etický, na nichž nic materialistického najít nemůžeme. Odkud se vzala tato víra? Bezesporu z křest’anství.

Průběh realizace komunismu toto skryté pozadí mnohokrát dokázal. Dokázala to historická skutečnost, že nejradikálnější pokus o vybudování komunistické společnosti byl uskutečněn v pravoslavném a konzervativním Rusku. Dokázala to fanatická víra první generace budovatelů komunismu v Rusku, víra, která posléze vedla ke kultu neomylnosti Stalina. Zásadní role osobností (Lenin, Stalin, Mao-ce-tung, Castro) v realizaci komunismu, potřeba víry a nadšení, nesvědčí o tom, že komunismus může být plodem pouze ekonomického vývoje a rozporů $\mathrm{v}$ ekonomické základně. Autor této stati se v hodnocení niterné blízkosti komunismu a křest'anství plně shoduje s ruským fillosofem Nikolajem Berd'ajevem, který sice komunismus kritizuje jako „bezbožnost“, avšak vidí i hluboce křest'anské znaky, které na sebe ruský komunismus vzal a kterými do značné míry naplňoval i křest’anskou eschatologii. Zběsilost, se kterou první generace komunistů ničila v Rusku vše tradiční, náboženské, historické měla podle něj určité historické oprávnění - jako trest: „Revoluce v křest’anských dějinách byly vždy soudem nad historickým křest'anstvím, nad křest'any, nad jejich zradou křest’anských zásad, nad deformací křest'anství. Právě pro křest’any má revoluce smysl, a především oni by ho měli pochopit, nebot' je pro křest’any výzvou a připomenutím jejich nerealizované pravdy.“60 Berd’ajev připomíná, že základní křest’anské ctnosti jako schopnost oběti, byly současně neoddělitelné od mentality lidí, kteří uskutečňovali komunistickou revoluci a posléze začali budovat komunismus. „Nejlepší typ komunisty, tj. člověka cele sloužícího ideji, schopného nesmírných obětí a nezištného entuziasmu, mohl vzniknout jen v důsledku křest’anské výchovy, $\mathrm{v}$ důsledku přetvoření lidské duše a přirozenosti v křest’anském duchu. “61 Jestliže tyto vlastnosti v lidech vyschly, stali se pro komunismus nepoužitelní, ale i komunismus se stal bez takových lidí nerealizovatelný a neživotný.

Marx sám žádným ,anti-křest’anem“ nebyl. Tak jako Feurbach odmítl náboženství, protože skutečně št'astná lidská společnost měla být naplněna zde na zemi, a neměla být jen snem, který se možná splní v záhrobí. Marxovými slovy: „Zrušit náboženství jako iluzorní štěstí lidu znamená žádat jeho skutečné štěstí....Kritika strhla z okovů imaginární květy, ne proto, aby člověk vlekl dál bezútěšné okovy, nezkrášlené fantazií, nýbrž aby tyto okovy odhodil a utrhl

\footnotetext{
59 „Obžaloby proti komunismu, vznášené z náboženských, filosofických a vůbec ideologických hledisek si nezasluhují obšírnější rozbor.“ - Karel MARX, Bedřich ENGELS, Manifest komunistické strany, In: Čítanka marxistickej filozofie, sv. I K. Marx, F. Engels, Bratislava 1963, s. 31.

${ }^{60}$ Nikolaj Alexandrovič BERĎAJEV, Prameny a smysl ruského komunismu, Praha 2012, s. 146.

61 Tamtéž, s. 187.
} 
živý květ.“62 Jeho okř́ílený výrok o „náboženství jako opiu lidu“ 63 je potřeba vidět v souvislosti s tehdejším životem: za stavu tehdejší lékařské vědy to bylo často to jediné, čím se mohlo trpícímu pomoci (a bohužel to $\mathrm{v}$ některých případech platí i dnes). Morální podstata komunismu zůstávala př́tomna navzdory dialekticko-historicko materialistické formě, kterou vytvořili Marx a Engels, jejich ateismus, který se vlivem Leninovým proměnil v anti-teismus, nenávist $\mathrm{k}$ náboženství, který samotný zase můžeme pokládat za postoj svého druhu náboženský, ${ }^{64}$ a kult vědy a techniky, vytvořily státem vynucované „náboženstvi““, kde etické složky v pozoruhodné symbióze koexistovaly s dobovými představami, náladou, mýty, ale i „opilostí“ mocí, která se dostavila u vítězných revolucionářů. Skutečnost, že komunismus v někdejším Rusku na sebe vzal formu víry, která se bezpodmínečně a dogmaticky vyžadovala, svědčí o tom, že společnost bez víry, ideálů a nejspíš i idolů, jakkoliv právě nejrůznější idoly a mýty chtěl původně Marx svou vědou zbořit v zájmu ,skutečného člověka“, nemůže a asi ani nechce existovat. Představy že ,elektřina zaujme místo Boha. Rolník necht' se modlí k elektřině; moc ústředních orgánů pocítí více než moc nebe, “65 či bojové, pogromistické básnictví: „My tě dorazíme, romantiku světe! Duši mít z pověr? Ne! Z páry a elektriky. Z kapes všech světů si bohatství přivlastněte! Stár? Pryč z tebou! Z lebek popelníky!“ “, ${ }^{66}$ můžeme chápat za projevy v podstatě naivní víry, že na místo víry se svět nadále bude řídit jen vědou a technikou, která ho napraví a dovede ke štěstí, ale i za eschatologii revolucí zásadně proměněného nového světa, který $\mathrm{v}$,poslední bitvě“ porazil svět starý. Násilný střet komunismu s křest’anstvím by tragický, když sám komunismus hodnotově vyrostl na půdě křest'anství a lze ho, spolu s jinými historicko-ideovými útvary, jako byl humanismus, chápat jako větve jednoho křest'anského stromu. Chtěli-li bychom toto tvrzení radikalizovat, mohli bychom na komunismus pohlížet jako na dobovou aktualizaci křest'anství na podmínky 19. století a kapitalismus, když na starší verzi bylo pohliženo jako na neužitečnou, matoucí či př́ímo škodlivou.

\section{Závěr}

Moderní komunismus je neoddělitelný od učení Karla Marxe, který se ho spolu s Bedřichem Engelsem pokusil postavit na pevnější filosoficko-metodologické základy, spočívající na dialektickém a historickém materialismu a tak zvaném vědeckém světovém názoru. Marxův filosofický vývoj však byl složitý, původně nebyl ani materialistou a komunismus odmítal jako „dogma“. Pokusili jsme se ukázat, že Marxova dialekticko-materialistická fáze je s jeho předchozí kriticko-idealistickou fází spojena hlouběji než jen časově-kauzálně či logicky, a že i v této fázi svým způsobem, latentně, nepřiznaně pokračuje idealismus a kriticismus, kterými Marx uchopuje realitu, byt' na povrchu a s postupujícím časem se Marxův jazyk stále více

\footnotetext{
62 Karel MARX, Úvod ke kritice Hegelovy filosofie práva, in: Karel MARX, Bedřich ENGELS, Spisy sv. 1, Praha 1961, s. 402.

63Tamtéž, s. 402.

${ }^{64}$ Berd'ajev: „Militantní osvícenství obvykle získává formu militantního ateismu. Rozum, který se stal svým pánem a osvobodil se od tradic, jež ho spoutávaly, se staví proti viře v Boha. Vždy však jde pouze o přechodné stadium, kdy si rozum neuvědomuje, nakolik závisí na negativních afektech, ale vyspělejší rozum, skutečně svobodnější, si uvědomuje své hranice a svůj postoj $\mathrm{k}$ náboženské víre mění. Ruský osvětářský rozum se nachází v prvním militantním stadiu a je zcela $v$ moci afektů a emocí. Vidíme to u Lenina. Lenin byl vášnivý a přesvědčený ateista a náboženství nenáviděl. Říkám 'ateista', třebaže nevěrím v existenci ryzích 'ateistư'“ (Nikolaj Alexandrovič BERĎAJEV, Prameny a smysl ruského komunismu, Praha 2012, s. 176-177).

${ }^{65}$ Lenin v diskusi s Leonidem Krasinem o elektrifikaci Ruska v roce 1918 - Dmitrij VOLKOGONOV, Lenin: Počátek teroru, Liberec 1996, s. 306.

66Vladimír Majakovskij. „150 000 000“, in: Andrej Zubov, Dějiny Ruska 20. století - díl I, Praha 2014, s. 729.
} 
„povědečt’uje“, konkretizuje (do sféry ekonomie) a Marx se hlásí k dialektickému a historického materialismu a s většinou svým souputníků i učitelů z mladšího období se leckdy velmi ostře rozchází. Tento stav jsme nazvali implicitní př́tomností kriticko-idealistické fáze ve fázi dialekticko-historicko materialistické.

Marxovým (ale za významného př́spěvku též Bedřicha Engelse) přičiněním ideály komunismu, které po staletí zůstávaly skrytě přítomné v evropské kultuře a byly artikulovány v nejtěsnější souvislosti s křest’anstvím a leckdy odvozovány přímo z něho, a jen ve výjiměčných situacích probublávaly na povrch či se dokonce stávaly „materiální silou“ dějin, byly postaveny na základ nové filosofie - vědy, která sama sebe označovala za vědecký světový názor. Tato transformace komunistického ideálu ve vědu měla dalekosáhlé následky pro další charakter komunistického hnutí a je nejspíš nejdůležitějším příspěvkem Marxe a Engelse nejen $\mathrm{k}$ dějinám myšlení, ale $\mathrm{i}$ ke skutečným, hmatatelným a žitým lidským dějinám. Na rozdíl od většiny jiných filosofư Marxovo dílo a „vědecký světový názor“ se vskutku staly návodem k postavení ke kapitalismu alternativního světa.

\section{Seznam použitých zdrojů}

Nikolaj Alexandrovič BERĎAJEV, Prameny a smysl ruského komunismu, Praha 2012.

Jonathan BEECHER; Richard BIENVENU (eds.), The Utopian Vision of Charles Fourier Selected Texts on Work, Love and Passionate Attraction, USA 1983.

Paul BÉNICHOU, Le Sacre de l'écrivain: Doctrines de l'âge romantique, Paris 1977.

Auguste CORNU, Karel Marx, Bedřich Engels, Praha 1963.

Erinnerungen an Karl Marx, Berlin 1953.

Milan LUPTÁK, Vladimír PROROK, Politické ideologie a teorie. Od starověku po rok 1848, Plzeň 2011.

Čítanka marxistickej filozofie, sv. I., K. Marx, F. Engels, Bratislava 1963.

Karel MARX, Bedřich ENGELS, SPISY sv. 1, Praha 1961.

Karel MARX, Bedřich ENGELS, SPISY sv. 2, Praha 1957.

Rolf HOSFELD, Karl Marx. Životopis intelektuála, Praha a Litomyšl 2013.

David MCLELLAN, Karl Marx. Leben und Werk, München 1974.

PLATON, Ústava, Bratislava, 1980.

Dmitrij VOLKOGONOV, Lenin: Počátek teroru, Liberec 1996.

Andrej ZUBOV, Dějiny Ruska 20. století - díl I, Praha 2014.

\section{Internetové zdroje}

Bedřich ENGELS, Vývoj socialismu od utopie k vědě, část III Historický materialismus, Online Version: Marx/Engels Archive (marxists.org) 2010: https://www.marxists.org/cestina/marx-engels/1880/socutop/ch03.htm

Karel MARX, Bída filosofie, Online version: http://www.kmbe.cz/BidaFilosofieFinal.pdf, s. 94.

Karel MARX, Teze o Feurbachovi, Online version: https://www.marxists.org/cestina/marx-engels/1845/tezefeuerbachovi.htm . 